\title{
MILOSIERNI JAK OJCIEC, CZYLI O NAJWIĘKSZEJ CNOCIE WYCHOWAWCY
}

\begin{abstract}
Streszczenie: Wychowywanie jest dziełem trudnym i wymagającym dużej wrażliwości na drugiego człowieka oraz odpowiedzialności za jego rozwój. Dlatego każda inspiracja pomagająca $\mathrm{w}$ tym dziele $\mathrm{w}$ taki sposób, by wychowanek był wspierany w ujawnianiu i rozwijaniu własnych możliwości, $\mathrm{w}$ dążeniu do spełnienia siebie $\mathrm{w}$ relacjach $\mathrm{z}$ innymi, zasługuje na szczególną uwagę pedagogów - teoretyków i praktyków. Jedną z takich inspiracji, nie tylko dla katolików, może być hasło ogłoszonego przez papieża Franciszka Roku Miłosierdzia - „Miłosierni jak Ojciec”. Pedagogom przypomnieć ono może dwa ważne wyznaczniki pomyślnej pracy wychowawczej, dość poważnie przytłumione przez współczesną kulturę, jakimi są cnota miłosierdzia i ojcostwo. Prezentowany artykuł stanowi próbę ukazania ich inspirującej siły w dziele wychowania.
\end{abstract}

Słowa kluczowe: cnota miłosierdzia, wychowanie, wychowawca, ojciec

\section{Odrzucane źródła inspiracji w pracy wychowawczej}

W trudnym i wymagającym odpowiedzialności za drugiego człowieka dziele wychowania każda inspiracja budząca wrażliwość na ludzkie istnienie i jego rozwój może być na wagę udanego i dobrego życia konkretnej osoby czy wspólnoty. Różnorodnych ożywczych impulsów może dostarczyć wychowawcom przede wszystkim codzienność, niosąc zarówno to, co nie było do przewidzenia, jak i zaplanowany wcześniej programowo system czynności oraz częściowo tylko przewidywalne interakcje $\mathrm{z}$ wychowankiem, a także inicjatywy wychodzące od tego ostatniego. Bogatych inspiracji wychowawczych dostarczyć może również obfita i zróżnicowana, choć nie zawsze jednoznaczna w swojej wartości moralnej (dlatego wymagająca wnikliwej i krytycznej oceny) oferta kulturowa. Cennym źródłem dynamizowania pracy wychowawczej może być także religia, stanowiąca integralną część kultury. I ta oferta wymaga czujnej weryfikacji przez wychowawcę. Trudno się bowiem zgodzić z obecnie poprawnym politycznie hasłem „wszystkie 
religie są równe", gdyż rzekomo (i tu polaryzują się głosy decydentów politycznych oraz opinii społecznej) - jak twierdzą jedni - wszystkie proponują to samo, w tym miłość do drugiego człowieka, albo - jak głoszą inni - wszystkie są narzędziem opresji wobec bezbronnej jednostki.

Przyjęcie pierwszego stanowiska prowadzić może do bezkrytycznej, a nie tolerancyjnej - jak chcą jej propagatorzy - postawy jednostki wobec doktryn poszczególnych religii. W przypadku niedojrzałych społecznie czy intelektualnie albo też zranionych emocjonalnie uczestników wychowania postawa taka nierzadko skutkuje uzależnieniami o charakterze sekciarskim, swoistym ubezwłasnowolnieniem. Przyjęcie drugiego stanowiska zmierza z kolei do walki z wszelkimi przejawami religii, niezależnie od ich wartości, do spychania każdego przejawu życia religijnego w sferę tabu, do wyjaławiania kultury, nasyconej do niedawna znaczeniami ukształtowanymi na gruncie konkretnej wiary religijnej, z obecności tych znaczeń. Czyni się tak, nie bacząc na to, że przez tę swoistą redukcję kultury, w orbitę której włącza się religia, dokonuje się również redukowania możliwości rozwojowych jednostki w relacji do siebie i ludzkiej wspólnoty.

Wychowawcze procesy wspomagania rozwoju człowieka do pełni człowieczeństwa stają się przez to uboższe, sztucznie ograniczone, realizowane są przy pomocy skromniejszych środków. Tymczasem logika myślenia pedagogicznego podpowiada, że wymagają one krytycznego i odpowiedzialnego korzystania ze wszelkich możliwych inspiracji, których owocem będzie dobro jednostki, jej szczęście, nie niweczące dobra i szczęścia drugiej istoty ludzkiej. Wychowawca, dla którego mogą się one okazać nieocenionym czynnikiem wartości jego pracy, uczestniczy w niezwykle doniosłej twórczości. Jest to bowiem „twórczość o przedmiocie najbardziej osobowym [...], twórczość w tworzywie całkowicie ludzkim”. Karol Wojtyła - autor tych słów - rozwijając swą myśl, pisze: „wszystko, co z natury zawiera się w wychowywanym człowieku, stanowi tworzywo dla wychowawców, tworzywo, po które winna sięgać ich miłość" (Wojtyła 1981, s. 54; Sztaba 2015, s. 47). Miłość jest bowiem jedynym właściwym odniesieniem człowieka do człowieka, w którym podmiot działań traktuje drugą osobę jako dobro samo w sobie, a nie instrumentalnie wykorzystywany środek prowadzący do innego celu, wykraczającego poza to dobro (tamże, s. 42).

W pedagogicznej refleksji nad istotą roli wychowawcy w ogóle, a w szczególności zawodowego wychowawcy, jakim jest nauczyciel, pojęcie miłości pojawia się dzisiaj niezbyt często. Jest to zapewne skutkiem tego, że współczesna kultura masowa, a także działania polityków czy ideologów deprecjonują i banalizują wiele nośnych pedagogicznie kategorii, czyniąc z nich pusto brzmiące słowa, tracące swoje pierwotne znaczenie. Miłość także znalazła się pośród nich, ale jeszcze bardziej związane z nią integralnie miłosierdzie, kojarzone współcześnie głównie $z$ retoryką kościelną, wyznaniową. O ile bowiem znajdziemy w polskiej twórczości pedagogicznej trochę przykładów obecności kategorii miłości w charakterystyce procesów wychowawczych, o tyle kategoria miłosierdzia nie zaznaczyła się w niej 
w sposób wyrazisty. Spróbujmy zatem przyjrzeć się jej z perspektywy pedagoga, stawiając pytanie o możliwości wykorzystania jej jako inspiracji do określenia istotnych właściwości osoby i działania wychowawcy.

\section{Miłosierdzie jako największa z cnót w relacjach międzyludzkich}

Poszukiwanie odpowiedzi na tak postawiony problem można rozpocząć w dalekiej przeszłości, sięgając do twórczości św. Tomasza z Akwinu. W Sumie teologicznej (S.Th.) w tomie zatytułowanym Miłość sformułował on pytania o to, czy miłosierdzie jest cnotą i czy jest największą z cnót. Przypomnijmy, że cnota jest sprawnością umożliwiającą spełnianie czynów, i to tych dobrych. Ukierunkowanie sprawności na czyny złe wiąże się z przeciwieństwem cnót - z ludzkimi wadami. W zrozumieniu Tomaszowej nauki o cnotach pomocny jest o. Jacek Woroniecki, który - o czym pisze jego wybitny uczeń Stefan Swieżawski - „wyraźnie odróżniał odruch od czynu i nawyk od sprawności”, wskazując na różnice pomiędzy aktywnością ludzi i zwierząt: „Zwierzęta mogą dojść do nawyku, i na wytwarzaniu w nich nawyków polega cała tresura zwierząt, ale tylko człowiek może mieć sprawności. Otwiera się tu cała wielka dziedzina cnót i wad, której nie ma w zwierzęciu. Odruchy, wspólne nam i zwierzętom, mogą być moralnie obojętne, ale czynów obojętnych nie ma. Każdy nasz czyn [...] usprawnia nas dodatnio albo ujemnie" (Swieżawski 2002, s. 166).

Kierując uwagę na wychowanie, św. Tomasz sprzeciwiał się intelektualizmowi etycznemu Sokratesa, który podkreślał wagę kształtowania myślenia etycznego i zakładał, że dobre myślenie implikuje dobre czyny. Akwinata kładł natomiast nacisk na konieczność powtarzania czynów usprawniających dwie władze duchowe człowieka: intelekt i wolę. Cel tego swoistego „ćwiczenia się” w czynach jest taki, by miał on (człowiek) coraz większą łatwość w dobrym postępowaniu. Istotą cnoty w ujęciu św. Tomasza - nie jest bowiem tak jak u stoików czy u Immanuela Kanta trud, udręka w spełnianiu czynów, ale coraz większa łatwość. Chodzi o to, by dobre „uczynki przychodziły nam [...] coraz łatwiej” (tamże, s. 167).

Zasadniczą rolę w odkryciu kierunku, ku któremu zmierza czyn cnotliwy, przyznawał św. Tomasz intelektowi. Dlatego przechodząc już do rozważań o miłosierdziu, nie był gotów uznawać je za cnotę, jeśli miałoby ono oznaczać jedynie uczucie, „poruszenie dążeń zmysłowych”, wyrażające się w „bólu z powodu cudzych cierpień". Zdecydował się jednak na takie jego zakwalifikowanie ze względu na to, że może być ono „poruszeniem dążeń umysłowych, gdy mianowicie komuś nie podoba się, że kogoś spotyka zło. Otóż to [...] poruszenie może być kierowane prawidłami rozumu, a następnie według tych prawideł kierować ruchem uczuciowym jako niższym" (Św. Tomasz 1967, s. 135-136; S.Th. 2-2, q. 30, a. 3).

Św. Tomasz wskazuje na pobudki miłosierdzia: „«miłosierdzie jest współczuciem, powstającym w naszym sercu na skutek nieszczęścia cudzego, zmuszającym nas do przyjścia z pomocą, w miarę możności» [...], słowo «miłosierdzie» znaczy, że w naszym osierdziu, czyli sercu, mamy litościwą miłość (współczucie) dla nieszczęścia 
cudzego. Nieszczęście zaś jest przeciwstawnością szczęścia, które polega na mieniu tego, czego się chce" (tamże, s. 131; S.Th. 2-2, q. 30, a. 1). Tu jednak podkreślmy $\mathrm{z}$ mocą, że „według Augustyna [...] «szczęśliwym jest ten, kto ma to, czego chce, a nie chce niczego złego»" (tamże, s. 131; S.Th. 2-2, q. 30, a. 1).

Rozwijając tę myśl, trzeba przyjrzeć się bliżej temu, czego człowiek może chcieć w ogóle (a w szczególności w sytuacjach wychowawczych). Wykorzystując dalej myśl Akwinaty i św. Augustyna, „człowiek może czegoś chcieć, [...] po pierwsze, pożądaniem naturalnym. I tak wszyscy chcą być i żyć. Po drugie, chce rzeczy nie dla niej, lecz dla tego, co ona sprawia" (tamże, s. 131; S.Th. 2-2, q. 30, a. 1). Przykładowo „ktoś chce jeść coś szkodliwego dla zdrowia, mówi się o nim, że chce chorować, bo chce przyczyny choroby" (tamże, s. 132; S.Th. 2-2, q. 30, a. 1).

$\mathrm{Z}$ tą analizą ludzkiego chcenia należy powiązać „pobudki miłosierdzia, czyli współczucia”. Pierwszą z nich jest „to, co jest sprzeczne z pożądaniem naturalnym chcącego, a tym jest każde zło, które szkodzi i zasmuca, czego przeciwieństwa człowiek chce swą naturą”. Św. Augustyn wyraża to słowami: „ «miłosierdzie jest jakby smutkiem na widok zła mogącego bliźniemu zaszkodzić, lub go zasmucić»" (tamże, s. 132; S.Th. 2-2, q. 30, a. 1). Drugą jest zaskakujący, niespodziewany charakter zła, które spada na człowieka. Św. Augustyn mówi, „że te zła budzą współczucie, które «są przypadkowe», czyli «gdy przydarzyło się zło, kiedy ktoś spodziewał się dobra»" (tamże, s. 132; S.Th. 2-2, q. 30, a. 1). Trzeba też tu dodać trzecią pobudkę - otóż szczególnego miłosierdzia wymaga sytuacja, w której „wszystko, co ktoś czyni dobrze, wychodzi na złe” - „miłosierdzia najbardziej godny jest ktoś, kto cierpi niezasłużenie" (tamże, s. 132; S.Th. 2-2, q. 30, a. 1).

Św. Tomasz wyznacza granice pomiędzy miłosierdziem a postawą swoistej naiwności czy bezrefleksyjności w związku z kwestią winy. Stwierdza, że w swej naturze wina nie pociąga za sobą miłosierdzia, jest przecież dobrowolna. Jeśli jednak sprawca, grzesznik, odczuwa ją jako „coś, co jest przeciwne [jego] woli”, "może pobudzać do miłosierdzia”, „wzbudza współczucie i litość” (tamże, s. 132; S.Th. 2-2, q. 30, a. 1).

Cnota miłosierdzia - jak każda inna - „czyni dobrym tego, kto ją ma”. Dla wierzącego chrześcijanina człowiek jest tym lepszy, im bardziej upodabnia się do kochającego Boga, a w odniesieniu do Niego „miłosierdzie Jego ponad wszystkie dzieła Jego" - jak czytamy w Psalmie 144. Chrystus mówi do słuchających go: „bądźcie miłosierni, jako i Ojciec wasz miłosierny jest” (Łk 6, 36). To właśnie „W miłosierdziu [...] najwyraźniej wyraża się wszechmoc” Boga. Z tych powodów uchodzi ono za największą czy też najwyższą cnotę. „Jej właściwością bowiem jest dawanie innym, a co więcej zaradzać potrzebom cudzym, a to jest dowodem wyższości” (tamże, s. 137-138; S.Th. 2-2, q. 30, a. 4). Możemy powiedzieć, że jest to dowodem asymetrii w relacjach międzyosobowych, ale wyższość ta - wynikająca $\mathrm{z}$ asymetrii - nie godzi w wartość żadnej osoby, przeciwnie - ma ją na uwadze, o czym będzie jeszcze mowa w dalszej części rozważań. 
Wracając do myśli Akwinaty, trzeba do poprzedniej konkluzji (o miłosierdziu jako największej cnocie) wnieść pewne zastrzeżenie: „od strony mającego ją miłosierdzie nie jest największą cnotą, chyba że ten, kto ją ma, jest kimś najwyższym, kogo nikt nie przewyższa, a on ma wszystkich pod sobą. Dla kogoś bowiem, kto ma kogoś ponad sobą, jest czymś ważniejszym i lepszym złączyć się z istotą wyższą niż dbać o potrzeby niższych. Dlatego to biorąc pod uwagę człowieka, który ma Boga ponad sobą, miłość, dzięki której jednoczy się z Bogiem, jest ważniejsza niż miłosierdzie, którym zaopatruje potrzeby bliźnich. Natomiast jest miłosierdzie największą cnotą pomiędzy wszystkimi cnotami odnoszącymi się do bliźniego" (tamże, s. 138; S.Th. 2-2, q. 30, a. 4). Ta ostatnia konkluzja jest niezwykle nośna wychowawczo. Relacje wychowawcze są bowiem relacjami międzyludzkimi, w których wszyscy jesteśmy równi w swojej godności. Dla wychowawcy, mającego na uwadze własny stosunek do wychowanka, miłosierdzie jest cnotą najwyższą i najważniejszą. Także dla takiego, który nie ma wiary w Boga, gdyż wychowanek staje wobec niego zawsze w sytuacjach, w jakich pojawiają się "pobudki miłosierdzia”: pewne zło (przeszkody, bariery), które szkodzi jego rozwojowi (na przykład, kiedy w kręgu najbliższej rodziny wychowanka są osoby uzależnione, dysfunkcjonalne), zaskakujące i trudne zdarzenia losowe, które niespodziewanie na niego spadły (ciężka choroba, śmierć rodzica), czy sytuacje, gdy jego działanie - pomimo dobrych chęci - nie przyniosło dobrego rezultatu (przykładowo, kiedy wysiłek przyswojenia wiadomości z trudnego dla ucznia przedmiotu nie doprowadza do zrozumienia treści, ale skutkuje otrzymaniem oceny niedostatecznej).

\section{Wrażliwość na ludzkie słabości i nieszczęścia jako punkt wyjścia kształtowania cnoty miłosierdzia}

W tradycji judeochrześcijańskiej pojawia się wiele myśli pogłębiających rozumienie miłosierdzia, ważnych w szczególny sposób dla społeczności wychowawców. Cennym przykładem ich uporządkowania i głębokiej analizy jest ogłoszona 30 listopada 1980 roku encyklika Jana Pawła II Dives in misericordia (DM). Sięgając do Starego Testamentu, papież ukazuje obraz miłosierdzia Boga w stosunku do Izraelitów i stwierdza: „W miłosierdziu Boga dla swego ludu ujawniają się wszystkie odcienie miłości: On jest jego Ojcem (por. Iz 63,16), ponieważ Izrael jest Jego pierworodnym synem (por. Wj 4,22), jest także oblubieńcem tej, której Prorok oznajmia nowe imię: ruhama, «umiłowana», ponieważ jej będzie okazane miłosierdzie (por. Oz 2,3)" (Jan Paweł II 1996, s. 66; DM, pkt 4). Ojciec i oblubieniec to dwie różne figury miłosierdzia. Pierworodny syn i oblubienica uosabiają tych, którzy są obdarowani miłosierdziem. Ojciec i oblubieniec to również cenne metafory dla określenia istoty bycia wychowawcą. Choć trzeba dodać - w związku z deprecjonowaniem przez współczesnych figury ojca (o czym będzie jeszcze mowa w końcowej części rozważań) - nie każdy ojciec i zapewne też nie każdy współczesny oblubieniec, z których dość liczni już u progu małżeństwa (u wielu współczesnych 
również będącego w niełasce) zakładają jego tymczasowość i możliwość rozpadu. Pierworodny syn i oblubienica to z kolei trafne metafory na określenie osoby wychowanka. Obie figury uosabiają tych, którzy wymagają szczególnej troski i miłości. Pierworodny syn to bowiem nie tylko ktoś w jakiś szczególny sposób wyróżniony, ale to również ktoś zmuszony przechodzić przez bardzo trudne doświadczenia. $\mathrm{W}$ relacjach międzyludzkich narażony jest bowiem na poważne błędy swoich rodziców jako ten, który „zbiera ich grzechy”, między innymi w postaci poważnych błędów wychowawczych. Zatem jest to syn, który domaga się szczególnej troski, ochrony. Obraz wychowanka jako pierworodnego syna dopełnia metafora oblubienicy. Wychowanek bowiem to ten, kto wymaga miłości prawdziwej - „wielkiej miłości”, bezwarunkowej, gotowej wybaczać wszystko, choć jednocześnie roztropnej, która nie jest naiwna, by ową naiwnością nie szkodzić obdarowanemu miłością.

Autor Dives in misericordia zwraca uwagę na to, że w księgach Starego Testamentu znajdziemy dwa wyrażenia na określenie istoty miłosierdzia: hesed i rahamim. W przypisie dotyczącym pierwszego z nich czytamy: „Wyraz hesed wskazuje na swoistą postawę «dobroci». Jeśli taka postawa cechuje dwie osoby, wówczas one nie tylko obdarzają się życzliwością, ale są sobie wierne na zasadzie wewnętrznego zobowiązania, a więc także - każda $\mathrm{z}$ nich - na zasadzie wierności sobie samej. Jeśli hesed oznacza także «łaskę» czy «miłość», to właśnie w oparciu o taką wierność. Nie zmienia tego okoliczność, iż samo zobowiązanie, o jakie chodzi, miewa charakter nie tylko moralny, ale i prawny. Kiedy wyrażenie hesed Stary Testament odnosi do Boga, bierze zawsze pod uwagę Przymierze, które On zawarł z Izraelem. Przymierze to od strony Boga było darem i łaską dla Izraela. Jednakże w konsekwencji zawarcia Przymierza Bóg zobowiązywał się do jego wypełniania: $\mathrm{w}$ ten sposób hesed nabierał poniekąd treści prawnej. Obowiązek prawny ze strony Boga ustawał wówczas, gdy Izrael łamał zawarte z Nim Przymierze, gdy nie dotrzymywał jego warunków. Ale właśnie wtedy hesed, przestając być zobowiązaniem prawnym, odsłaniał swoje głębsze oblicze: okazywał się tym, czym był od początku, to znaczy obdarowującą miłością potężniejszą niż zdrada i łaską mocniejszą niż grzech" (tamże, s. 67; DM, pkt 4).

Hesed określa celnie pożądaną postawę wychowawcy, który obda rowując swoją dobrocią wychowanka, ma prawo oczekiwać od niego szacunku i życzliwości dla własnej osoby, ale gdy tego nie otrzymuje, a nawet doświadcza swoistej zdrady ze strony podopiecznego (na przykład niechęci do współpracy ucznia z nauczycielem w procesie kształcenia, objawiającej się między innymi niesubordynowanym zachowaniem podczas lekcji), nie porzuca go, nie zrywa z nim więzi, choćby ta była zerwana przez drugą stronę. Tak postępuje ukazany w Starym Testamencie miłosierny Bóg. Gdy doświadcza zerwania Przymierza ze strony narodu wybranego, pozostaje „wierny sobie samemu”, a oznacza to bycie „odpowiedzialnym za swą miłość". Owocem tej miłości, charakteryzującej się przymiotem hesed, jest bowiem przebaczenie i praca nad odbudową Przymierza (tamże, s. 67; DM, pkt 4). 
Rahamim jako drugie, obok hesed, wyrażenie spotykane w Starym Testamencie na określenie miłosierdzia ukazuje inny jego wymiar: „O ile bowiem to poprzednie uwydatnia cechy wierności samemu sobie i «odpowiedzialności za własną miłość» (a więc cechy jak gdyby męskie), o tyle rahamim już w swym źródłosłowie wskazuje na miłość matczyna (rehem = łono matczyne). $Z$ tej najgłębszej, pierwotnej bliskości, łączności i więzi, jaka łączy matkę z dzieckiem, wynika szczególny do tegoż dziecka stosunek, szczególna miłość. Można o niej powiedzieć, że jest całkowicie darmo dana, nie zasłużona, że w tej postaci stanowi ona jakąś wewnętrzną konieczność: przymus serca. Jest to jakby «kobieca» odmiana owej męskiej wierności sobie samemu, o jakiej mówi hesed. Na tym podłożu psychologicznym rahamim rodzi całą skalę uczuć, a wśród nich dobroć i tkliwość, cierpliwość i wyrozumiałość, czyli gotowość przebaczenia" (tamże, s. 67; DM, pkt 4).

Hesed i rahamim to wyrażenia oddające istotę Bożego miłosierdzia zgodnie ze swoistą „antropomorficzną «psychologią» Boga”. W jej świetle miłosierdzie jest miłością, która jest Bożą odpowiedzią na popełnione przez człowieka zło. Obok tych wyrażeń pojawiają inne, dopełniające obrazu miłosierdzia, niekiedy od nich szersze, innym razem wchodzące w ich zakres znaczeniowy. Między nimi: hanan - oznaczające „okazywanie łaski, które wyraża jakby stałe usposobienie wielkoduszne, życzliwe i łaskawe”; hamal - rozumiane jako „oszczędzanie (pokonanego wroga), ale również okazywanie litości i współczucia, a w konsekwencji przebaczenie i darowanie winy”; hus - „wyraża[jące] litość i współczucie w sensie nade wszystko uczuciowym” - oraz emet, „które naprzód oznacza «stałość» i «pewność» (w Septuagincie «prawdę»), a z kolei «wierność»" (tamże, s. 68; DM, pkt 4).

Ujawniający się w Starym Testamencie obraz miłosierdzia Bożego pokazuje ten przymiot jak syntezę ojcowskiej i matczynej miłości, która wprawdzie odwołuje się do zawartej umowy - Przymierza - z narodem wybranym i w związku $\mathrm{z}$ tym ukierunkowana jest na sprawiedliwe postępowanie, ale ponad nim stawia troskę o podopiecznego, gotowość do wybaczenia mu popełnionego zła, a przez to dbałość o jego dobro i szczęście. Miłosierdzie to pokazuje wyrozumiałość Boga wobec ludzkich niedoskonałości, Jego ogromną wrażliwość na słabość człowieka i dotykające go zawinione i niezawinione nieszczęścia.

Rozwijanie takiej wrażliwości to trudne, ale konieczne zadanie wychowawców, którzy pracując „w tworzywie całkowicie ludzkim”, powinni pamiętać, że jest to "tworzywo, po które winna sięgać ich miłość". Ta wrażliwość nie może być oparta na poczuciu wyższości. Nie tylko dlatego, że wychowawca nie jest Bogiem - choć ten ostatni w Nowym Testamencie, w Osobie Chrystusa, pomimo swej wszechmocy w imię miłości miłosiernej poniża samego siebie i staje się sługą ludzi, ich zbawicielem - lecz także dlatego, że podobnie jak wychowanek, jest człowiekiem z całym potencjałem wielkości i małości własnego człowieczeństwa. Świadomość własnej niedoskonałości, braków powinna skłaniać go do widzenia wychowanka nie jako uzależnionego od niego nieszczęśnika, ale raczej jako brata - bliźniego, 
narażonego na podobne niedole losu i w tych niedolach zasługującego na okazanie mu miłosierdzia.

\section{Miłosierny jak Ojciec}

Szczególnego obrazu miłosierdzia, obok powszechnie znanego wizerunku miłosiernego Samarytanina, dostarcza w Nowym Testamencie przypowieść o synu marnotrawnym. Historia młodego człowieka, który roztrwonił majątek kochającego go ojca, może być dla wychowawców swoistym zapisem ich najbardziej doniosłych powinności wobec wychowanków. Ojciec z tej przypowieści jest przede wszystkim „wierny swojemu ojcostwu”, czyli miłości do syna. Wierność ta wyraża się w następujących postawach i zachowaniach: natychmiastowej gotowości, by przyjąć syna do domu, autentycznej radości z jego powrotu, a co więcej-w geście szczodrego obdarowania marnotrawcy. To wszystko „budzi sprzeciw i zazdrość starszego brata, który nigdy nie odszedł od ojca i nie porzucił jego domu" (tamże, s. 72; DM, pkt 6).

Wydaje się, że nietrudno przełożyć obraz spotkania ojca z synem marnotrawnym na sytuację wychowawczą. Wówczas wychowawca stwarza wychowankowi szansę przeżywania własnej godności i razem z wychowankiem cieszy się jego wartością. W przywoływanej tu encyklice Dives in misericordia Jan Paweł II podkreśla, że wierność ojcostwu koncentruje się całkowicie na „człowieczeństwie utraconego syna, na jego godności” - „skazuje ojca na troskę o godność syna”. Pochylenie się ojca nad synem marnotrawnym sprawia, że ten pierwszy „nie czuje się poniżony, ale odnaleziony $\mathrm{i}$ "dowartościowany»", ponadto odzyskuje pewne dobro, które utracił, tym dobrem jest „powrót do prawdy o sobie samym” (tamże, s. 72-73; DM, pkt 6).

Wspólne (ojca i syna, wychowawcy i wychowanka) przeżycie tej prawdy - nie tylko o ograniczeniach, ale przede wszystkim właśnie o wielkości człowieczeństwa i godności każdego człowieka - czyni miłosierdzie relacją pogłębiającą zwykłą sprawiedliwość, opartą na zrównaniu i braterstwie. Ta konkluzja jest znacząca dla przełamania pewnego stereotypu myślenia oraz uprzedzeń wobec miłosierdzia, bo oto - jak zauważa Jan Paweł II - „Nieraz [...] dostrzegamy w miłosierdziu nade wszystko stosunek nierówności pomiędzy tym, kto je okazuje, a tym, który go doznaje. I z kolei gotowi jesteśmy wyciągnąć wniosek, że miłosierdzie uwłacza temu, kto go doznaje, że uwłacza godności człowieka. Przypowieść o synu marnotrawnym uświadamia nam, że jest inaczej: relacja miłosierdzia opiera się na wspólnym przeżyciu tego dobra, jakim jest człowiek, na wspólnym doświadczeniu tej godności, jaka mu jest właściwa. To wspólne doświadczenie sprawia, że syn marnotrawny zaczyna widzieć siebie i swoje czyny w całej prawdzie (takie widzenie jest autentyczną pokorą); dla ojca zaś właśnie $\mathrm{z}$ tego powodu staje się on dobrem szczególnym: tak bardzo widzi to dobro, które dokonało się na skutek ukrytego promieniowania prawdy i miłości, że jak gdyby zapomina o całym złu, którego przedtem dopuścił się syn" (tamże, s. 72-73; DM, pkt 6). Okazując w ten sposób 
miłosierdzie synowi, ojciec okazuje mu swoją miłość - „miłosierdzie jest bowiem nieodzownym wymiarem miłości, jest jakby drugim jej imieniem, a zarazem właściwym sposobem jej objawiania się i realizacji wobec rzeczywistości zła, które jest w świecie, które dotyka i osacza człowieka" (tamże, s. 77; DM, pkt 7).

Będąc relacją równości i braterstwa, jest też miłosierdzie w sytuacji popełnionego przez syna zła relacją przebaczenia ze strony ojca. To przebaczenie, którego uczy Chrystus opowiadający przypowieść o synu marnotrawnym, ma być permanentne i niedokonywane z pozycji wyższości - łaskawcy, który w niczym nie zawinił, ale ze świadomością, „że jesteśmy zwykle wzajemnie wobec siebie dłużnikami”. Taka świadomość ,idzie w parze z wezwaniem do tej braterskiej solidarności, której św. Paweł dał wyraz w [...] wezwaniu: «Jeden drugiego brzemiona noście» $(\mathrm{Ga} 6,2)$ " (tamże, s. 95; DM, pkt 14). Zaraz po tych stwierdzeniach Jan Paweł II formułuje iście pedagogiczną konkluzję: „Jakaż w tym zawiera się lekcja pokory wobec człowieka równocześnie bliźniego i siebie samego - jakaż szkoła dobrej woli współżycia na każdy dzień i w różnych warunkach naszego bytowania! Gdybyśmy odrzucili tę lekcję - cóż pozostałoby z jakiegokolwiek «humanistycznego» programu życia i wychowania" (tamże, s. 95; DM, pkt 14).

Lekcję tę pojął zapewne przed wielu laty Jan Władysław Dawid, przedstawiając myślenie nauczyciela, którego cechuje „miłość dusz ludzkich” - atrybut nauczycielskiego powołania: „Oto uczeń mój nie wie, nie rozumie, nie przeczuwa nawet tylu rzeczy ważnych, mądrych i potrzebnych; nie - to ja nie wiem jeszcze, nie rozumiem, to ja sam tą częścią moją, która jest nim. Uczeń mój postępuje źle, jest złośliwy, kłamie, krzywdzi; nie - to we mnie jeszcze tyle złego, w tej części mojej, która jest nim. Jakże boli mnie ta niewiedza, to zło - czyż z nimi mogę żyć!” (Dawid 1962, s. 45).

Wracając do myśli Jana Pawła II i mając na uwadze rzeczywistość wychowawczą, należy zwrócić uwagę na to, że przebaczenie oraz miłosierdzie w świetle ewangelicznego przesłania nie oznaczają pobłażliwości dla popełnionego zła. Domagają się one naprawy tego, co zostało zniszczone, zadośćuczynienia wyrządzonych krzywd (Jan Paweł II 1996, s. 95; DM, pkt 14). Postawa miłosierdzia w przypadku wychowawcy domaga się zatem postępowania wielkodusznego, ale jednocześnie wymagającego od wychowanka poszanowania godności innych.

Obok cytowanej wyżej encykliki Jana Pawła II szczególnych inspiracji wychowawczych w związku z cnotą miłosierdzia i jej odniesieniem do figury ojca dostarcza ogłoszony przez papieża Franciszka Rok Miłosierdzia (Nadzwyczajny Jubileusz Miłosierdzia Bożego), wyznaczony granicznymi datami: 8 grudnia 2015 r. i 20 listopada 2016 r. Nie sposób tu przywołać wszystkich kwestii istotnych dla zrozumienia jego znaczenia w samym Kościele katolickim. Nie jest to też właściwe miejsce, bo rozważania tu prowadzone ukierunkowane są na refleksję pedagogiczną. Wróćmy zatem do wątku wykorzystania przymiotu ojcowskiego miłosierdzia na polu wychowania. Hasłem Roku Miłosierdzia jest: „Miłosierni jak Ojciec”. Ilustruje je sugestywne logo autorstwa artysty i jezuity - ojca (nomen omen) Marka Ivana 
Rupnika. Przedstawia ono na tle krzyża Chrystusa jako Dobrego Pasterza, który bierze na swe barki Adama, czyli całą ludzkość, „czyniąc to z taką miłością, która przemienia życie". Jest coś szczególnego w tym wizerunku Chrystusa i Adama. Otóż „wzrok [Chrystusa] łączy się ze wzrokiem człowieka. Chrystus widzi oczami Adama, a Adam oczami Chrystusa" (Fisichelli 2016). Chrystus, który w sposób najdoskonalszy może przekazać istotę miłosierdzia Ojca, podnosi człowieka, który dopuścił się zła i cierpi. I utożsamia się z tym cierpieniem, rozumie je, patrząc na świat z perspektywy tego człowieka. Niosąc mu pomoc, podejmuje cierpienie na krzyżu, ukazując ludzkości, że nie cofnie się przed żadną ofiarą, która ma moc wydźwignięcia jej z upadku.

W bulli wydanej na Rok Miłosierdzia - Misericordiae vultus (MV) - papież Franciszek przypomniał, że Chrystus przybliżając w przypowieściach o miłosierdziu „naturę Boga”, ukazał ją jako „naturę Ojca”, który poprzez miłosierne i współczujące działanie zmierza do tego, by zniknął grzech i pokonane zostało odrzucenie (Franciszek 2015, s. 14; MV, pkt 9). Jednocześnie Franciszek wskazał na kolejny przymiot Bożego miłosierdzia - odpowiedzialność za człowieka, która oznacza, że Bóg „pragnie naszego dobra i chce nas widzieć szczęśliwymi, napełnionymi radością i pokojem" (tamże, s. 17; MV, pkt 9).

Odpowiedzialność wychowawcy za wychowanka można określić na podstawie tego, czy prowadzi on swego podopiecznego ku prawdziwej dojrzałości. Autentyczne szczęście, radość i pokój są bowiem udziałem ludzi dojrzałych, którzy biorąc los w swoje ręce, kształtują go, mając na uwadze własny potencjał (dla chrześcijanina własne powołanie) i możliwości obdarowania nim innych. Swoistym sposobem kształtowania tej odpowiedzialności przez wychowawcę przede wszystkim w sobie samym, ale też w wychowanku, mogą stać się przypomniane przez papieża Franciszka „uczynki miłosierne względem ciała: głodnych nakarmić, spragnionych napoić, nagich przyodziać, przybyszów w dom przyjąć, więźniów pocieszać, chorych nawiedzać, umarłych pogrzebać” oraz „uczynki miłosierne względem ducha: wątpiącym dobrze radzić, nieumiejętnych pouczać, grzeszących upominać, strapionych pocieszać, krzywdy cierpliwie znosić, urazy chętnie darować, modlić się za żywych i umarłych" (tamże, s. 25; MV, pkt 15). Tylko w jednym z powyżej przedstawionych uczynków wybrzmiewa w sposób bezpośredni aspekt wiary religijnej - „modlić się za żywych i umarłych”. Wszystkie pozostałe niosą ze sobą pewien uniwersalny program kształtowania wrażliwości na drugiego człowieka, ale i ten apelujący o modlitwę za żywych i umarłych raczej nie będzie budził sprzeciwu wrażliwych ateistów i osób dystansujących się od wiary, bo modlitwa rozumiana nie tylko wąsko - jako rozmowa z Bogiem czy innymi istotami duchowymi - lecz jako kontemplacja rzeczywistości, dialog człowieka z rzeczywistością, z pewnością jest nieobca każdemu otwartemu na świat człowiekowi. 


\section{Ograniczenia i możliwości wykorzystania obrazu ojcowskiego miłosierdzia we współczesnej pedagogice i rzeczywistości wychowawczej}

Miłosierny ojciec jako figura człowieka, który żyje w zbiorowości ludzi, to cenna oferta chrześcijaństwa dla ludzkości nękanej ciągłymi niepokojami i konfliktami. Jakie czynniki mogą ograniczyć jej wykorzystanie przez teoretyków i praktyków wychowania? Z pewnością należą do nich zjawiska, o których była mowa na początku rozważań: pewna kulturowa niechęć, by sięgać do depozytu religii, zwłaszcza religii chrześcijańskiej, oraz spychanie jej do sfery tabu. Pedagodzy są zawsze częścią konkretnych społeczności i podążając za trendami w nich dominującymi, również odrzucają czasem propozycje nieakceptowane w kręgach, do których przynależą. Taką odrzuconą propozycją może stać się miłosierdzie, rozumiane jako kategoria przynależna wyłącznie myśleniu religijnemu i utożsamiana również z niecenioną postawą litości, odczytywaną jako postawa wywyższania się jednych nad drugimi - tu: wychowawcy nad wychowankiem.

Można również żywić poważne obawy o nośność obrazu (miłosiernego) ojca. Jego postać kojarzona jest bowiem współcześnie z despotycznym patriarchatem, z nadużywaniem władzy, a ostatecznie ukazywana bywa jako niepotrzebna. Kulturowych źródeł tego stanu jest wiele. Swoiste „zasługi” w tej dziedzinie ma między innymi Jean-Paul Sartre, który jako filozof niewątpliwie znacząco wpłynął na przekonania kolejnych powojennych pokoleń młodzieży w Europie. Jego rodaczka i reprezentantka tej samej dyscypliny wiedzy Chantal Delsol, analizując autobiograficzny tekst Sartre’a, przedstawiła następującą charakterystykę i dość surową ocenę stosunku najpopularniejszego egzystencjalisty do ojcostwa: „Opisując swoje dzieciństwo w Słowach, Sartre cieszy się, że nie miał ojca. Ojciec - powiada z konieczności by go sobie podporządkował, bo tak chce obyczaj, ale na szczęście młody Jean-Paul był od wszystkiego wolny i mógł sobie wybierać, nie odnosząc się do nikogo. Jego system filozoficzny w naturalny sposób wypłynie z tego upojenia. Chodzi naprawdę o upojenie, bo opisane tu dziecko «wyskoczyło z zawiasów». Nie żyje w rzeczywistym świecie, lecz w świecie sztucznym, w każdym calu stworzonym przez dwie kobiety i starca, którzy go rozpieszczają. Jest fałszywym królem, fałszywym bogiem, a ostatecznie fałszywym dzieckiem. Zresztą sam to przyznaje. Jak być prawdziwym? - oto pytanie, które obsesyjnie powraca w tej opowieści. [...] Sartre pozostaje przykuty do zasady przyjemności. I staje się pisarzem, który spędza życie na okłamywaniu innych i okłamywaniu samego siebie" (Delsol 2011, s. 151).

O ograniczeniach i możliwościach optymalnego, służącego rozwojowi wychowanków wykorzystania obrazu ojcowskiego miłosierdzia w praktyce wychowawczej decydować może (na ogół w pewnym zespoleniu z wyżej wspomnianymi zjawiskami kulturowymi) szereg czynników podmiotowych, tkwiących w uczestnikach wychowania. Tu (z wyraźnym jednak podkreśleniem, że diagnoza wychowanka i społeczno-kulturowego kontekstu jego egzystencji są zawsze podstawą do działań wychowawczych, gdyż to właśnie on jest najważniejszą osobą, a jednocześnie 
głównym źródłem możliwości i ograniczeń w tych działaniach) wskazane zostaną głównie te, które dotyczą wychowawców.

Już samo rozumienie przez wychowawcę postawy miłosiernego ojca, a w jego następstwie praktyka kształtowania jej w sobie, narażone są na niebezpieczeństwo mylenia jej ze swoiście dobrotliwą pobłażliwością dla niewłaściwych zachowań wychowanków, a nawet naiwnością w obliczu nadużywania przez nich przejawów szeroko rozumianej dobroci wychowawcy. Dlatego tak ważne w formalnym i nieformalnym procesie (samo)kształtowania miłosierdzia wychowawców jest budzenie wrażliwości na wartość czynu wychowanka i potrzeby jego oceny. W przypadku, gdy ocena ta odsłania prawdę o czynie jako o działaniu złym moralnie, pierwszoplanową powinnością wychowawczą jest stworzenie sytuacji umożliwiającej wychowankowi „odkupienie winy”, zadośćuczynienie poszkodowanym, czyli wejście w sytuację kary. Nie stanowi ona odwetu ani tym bardziej nie jest narzędziem poniżenia wychowanka, ale - jak pisał Sergiusz Hessen (powołując się w tym miejscu na Hegla) - ,jest czcią przestępcy, oddawaną tylko człowiekowi wolnemu [...]. Dlatego sens kary tkwi nie w przyczynianiu przestępcy zła i nie w odstraszaniu, ale w ochronie "pokoju», tj. prawa, a w tym prawa samego przestępcy" (Hessen 1997, s. 200). Wychowawca mający na uwadze taki sens kary, nieposługujący się nią w sposób mechaniczny jako środkiem wychowania, stwarza swojemu podopiecznemu - zgodnie z regułami miłosierdzia - możliwość odbudowania godności osobistej w oczach własnych i innych osób.

Postawa ojcowskiego miłosierdzia u wychowawcy wymaga zatem dojrzałości i szczególnej wrażliwości moralnej, niemylonej z jednej strony z nadwrażliwością, a $\mathrm{z}$ drugiej - $\mathrm{z}$ drażliwością. To postawa pozbawionej naiwności akceptacji osoby wychowanka, odmienna również od paternalizmu, który niejako ubezwłasnowolnia tę osobę pod pretekstem prowadzenia jej ku dobru (dziś często utożsamianego nie z obiektywną wartością, ale z polityczną i kulturową poprawnością). Jest to postawa, która pozwala dojrzewać wychowankowi i daje mu możliwość ponoszenia konsekwencji własnych czynów, jednakże zawsze związana jest ona z obecnością wychowawcy, który czujnie mu towarzyszy, służy radą i pomocą, a w razie konieczności również interwencją $\mathrm{w}$ działanie wychowanka. Jak wypracować taką postawę? Oczywiście nie ma tu gotowej recepty, ale z pewnością kształtowanie tejże postawy domaga się autentycznego dojrzewania samego wychowawcy w relacjach do siebie i innych osób oraz świadczenia prawdy o własnym życiu w kontaktach z podopiecznymi.

\section{Bibliografia}

Dawid J.W. (1962). O duszy nauczycielstwa. W: Okoń W. (red.). Osobowość nauczyciela. Warszawa: PZWS.

Delsol C. (2011). Czym jest człowiek? Kurs antropologii dla niewtajemniczonych. Kraków: Wydawnictwo Znak. 
Fisichelli S. (2016). Logo i program Jubileuszu Miłosierdzia, dostępny na: http:/info. wiara.pl/doc/2467814.Logo-i-program-Jubileuszu-Milosierdzia (otwarty 25.02.2016). Franciszek (2015). Misericordiae vultus. O nadzwyczajnym Jubileuszu Miłosierdzia. Wrocław: Wydawnictwo Wrocławskiej Księgarni Archidiecezjalnej.

Hessen S. (1997). Podstawy pedagogiki. Warszawa: Wydawnictwo „Żak”.

Jan Paweł II (1996). Dives in misericordia. W: tenże. Encykliki Ojca Świętego Jana Pawła II, t. 1. Kraków: Wydawnictwo Św. Stanisława BM Archidiecezji Krakowskiej, Wydawnictwo M.

Swieżawski S. (2002). Święty Tomasz na nowo odczytany. Poznań: Wydawnictwo Polskiej Prowincji Dominikanów „W drodze”.

Sztaba M. (2015). Wychowanie jako „twórczość o przedmiocie najbardziej osobowym” w myśli Karola Wojtyły - Jana Pawła II. W: Sowiński A.J. (red.). Twórczość pedagogicznie ksztattowana. Gorzów Wielkopolski: Wydawnictwo Naukowe Państwowej Wyższej Szkoły Zawodowej im. Jakuba z Paradyża.

Św. Tomasz z Akwinu (1967). Suma teologiczna. T. 16 - Miłość, tłum. A. Gałażewski, Londyn: Katolicki Ośrodek Wydawniczy „Veritas”.

Wojtyła K. (1981). Miłość i odpowiedzialność. Lublin: Towarzystwo Naukowe Katolickiego Uniwersytetu Lubelskiego.

\title{
MERCIFUL LIKE THE FATHER - REFLECTIONS ON THE CHIEF VIRTUE OF AN EDUCATOR
}

\begin{abstract}
Education, being a difficult and demanding task, requires the educator to be deeply sensitive in his or her approach towards others, and to take responsibility for their development. Therefore, each and every inspiring idea that can be used for fulfilling this task to support children in revealing and developing their potential, and in striving towards self-fulfilment in their relationships with others, deserves the close attention of both practitioners and theoreticians of pedagogy. One such inspiring concept is the motto of the Holy Year of Mercy announced by Pope Francis - "Merciful like the Father." The motto can remind pedagogues of the two determinants essential to the successful work of educators, which have been to a considerable extent suppressed by contemporary culture, namely the virtue of mercy and fatherhood. The presented paper attempts to depict their power to inspire educational work.
\end{abstract}

Keywords: the virtue of charity, education, educator, father

Lucyna Dziaczkowska - doktor habilitowana, profesor KUL JPII, kierownik Katedry Filozofii Wychowania w Instytucie Pedagogiki Katolickiego Uniwersytetu Lubelskiego Jana Pawła II. Autorka monografii: Wizje zawodu nauczyciela $w$ Polsce u progu trzeciego tysiaclecia (2000), Wiedza o wychowaniu. Od różnorodności do jedności (2008), Podmiot i podmiotowość $w$ wychowaniu. Studium w perspektywie poznawczej pedagogiki integralnej (2008). Adres do korespondencji: ul. Niecała 8a/27, 20-08o Lublin. Adres e-mail: lucyna.gorska1@gmail.com. 